\title{
Adrenal Cortex Compact Cell Adenoma
}

National Cancer Institute

\section{Source}

National Cancer Institute. Adrenal Cortex Compact Cell Adenoma. NCI Thesaurus. Code C4163.

An adenoma of the adrenal cortex composed of neoplastic compact cells with eosinophilic cytoplasm. 